\title{
Research on the Concept of Occupational Orientation in the Employment Difficulties of Art Design Majors
}

\author{
Cheng Xi \\ Fuzhou Institute of Foreign Languages and Trade, School of Art and Design, Department of Visual \\ Communication Design, Fujian, China, 350202
}

Keywords: art design; college students employment; life orientation

Abstract: As a special group of college students, the art design students are not affected by their own special characteristics and the comprehensive factors such as school and society. Based on the in-depth analysis on the causes of the difficulties in the employment of art design students, this paper further proposes the countermeasures and countermeasures to solve the employment difficulties. It can be seen that the art design students have a comprehensive reason for their own employment, school and society. Therefore, to actively solve the employment problems of art design students, it is necessary to grasp the characteristics of students, strengthen employment guidance, improve the overall quality of guide students to shape themselves and actively seek employment in accordance with the requirements of social and economic development.

\section{Introduction}

With the expansion of colleges and universities, the difficulty of college students' employment has become a focus of attention of the whole society. As a special group of college students, art design students are more serious because of their special characteristics and the comprehensive factors such as school and society. The difficulty of employment in art design students has become a major social issue that cannot be ignored. Therefore, in order to solve the employment problems of art design students, it is necessary to analyze the causes of them in an in-depth manner and take effective measures in a targeted manner to actively promote student employment ${ }^{[1]}$.

\section{Analysis of the causes of employment difficulties in art design students}

In order to better understand the characteristics of art design students and the causes of employment difficulties, we conducted a field survey of art design students in the design art school of Changsha University of Science and Technology through a symposium and individual interviewsand in 200911 In November and November 2010, he conducted in-depth market research in Guangzhou, Shenzhen, Zhuhai and other places, visited 32 household units, conducted in-depth interviews with employers and alumni, issued questionnaires and listened to their training of art students. Comments and suggestions. Through the collation and analysis of various data, opinions and suggestions, we believe that the main reasons why art students have difficulty in employment are as follows ${ }^{[2]}$. The causes of the difficulty in employment of art design students are shown in 
Figure 1.

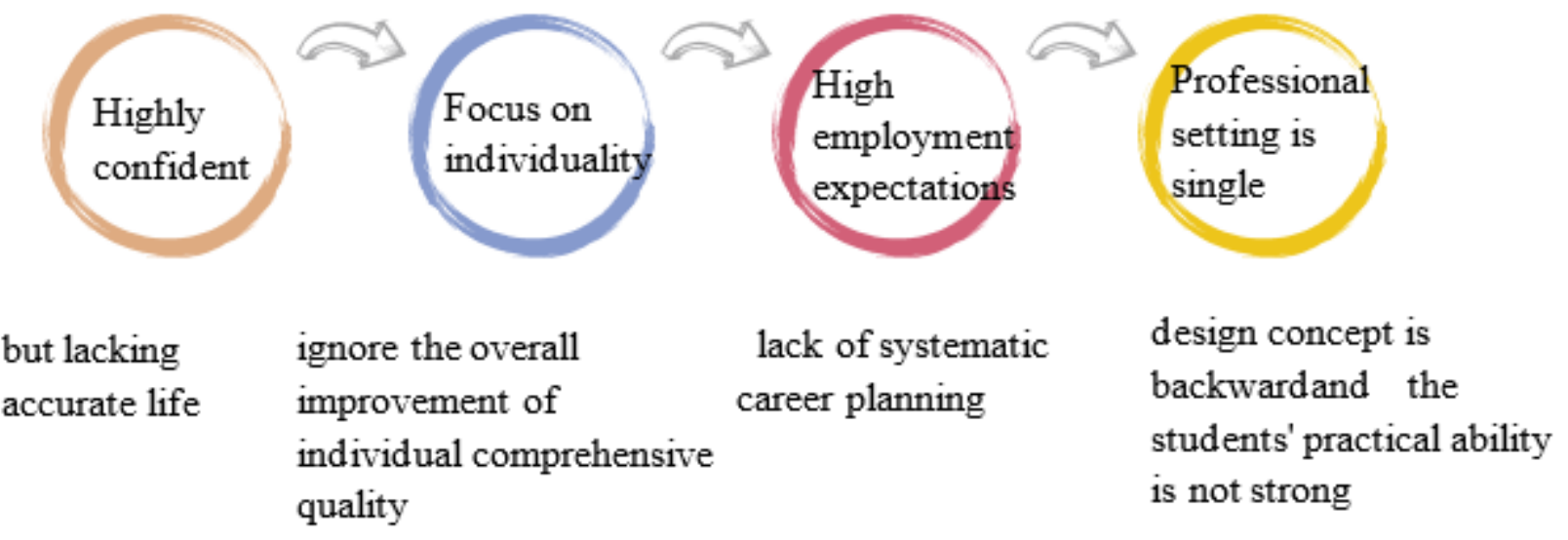

Figure 1 The causes of the difficulty in employment of art design students

\subsection{Highly confident, but lacking accurate life orientation}

Students in the art design category generally have ideals, ambitions and passions. They are full of good enthusiasm for life and society and they are full of self-confidence. However, due to lack of life and social experience, they often cannot analyze themselves accurately. To evaluate yourself, you cannot shape yourself in time according to the development of society and economy and carry out accurate life orientation. Once in contact with a complex society and in a variety of social networks with thousand s of threads, it is often at a loss and even the confidence that was originally established is swept away. Therefore, in the process of finding a job, there are often cases of high and low eyes and low hand s, which leads to the evaluation of the employer is not high.

\subsection{Focus on individuality, but ignore the overall improvement of individual comprehensive quality}

Although the mainstream ideals, beliefs, outlooks and values of art design students are positive, there are also trends of ambiguity in ideals, diversification of life values and individualization. Some students will even be unruly, silent and self-respecting. As a characteristic of "personality" of art students, they should adopt an attitude of indifference or even contempt for group activities, class activities, community activities and social practice activities and never actively participate, resulting in personal interpersonal, communication and verbal skills. Strong, lack of teamwork spirit $^{[3]}$.

\subsection{High employment expectations and lack of systematic career planning}

In line with the "high investment" of art design students, art design students have a "high return" expectation and desire for future work. If faced with the high-level study and training investment of more than 100,000 yuan in the previous period and finally only get a monthly salary of about 2,000 yuan, art design graduates are often difficult to make positive choices. Therefore, in the case of employers with lower benefits, many graduates prefer to pursue their own career and not employment. Even those students with financial difficulties in their families are forced to repay the family investment and borrowing pressure during the university. It is difficult to make positive choices, which is also an important reason for the difficulty of employment in art design students. At the same time, although art design graduates have high expectations for the future, they lack the necessary planning for their careers and future development. Many students lack the necessary 
thinking and understanding about their personality characteristics, comprehensive quality and advantages, society, business needs for talents and their own gaps. They just blindly pursue the coastal developed cities, with high income and good environment. The place to go to work, this objectively further increases the difficulty of employment for art design students ${ }^{[4]}$.

\subsection{The professional setting is single, the design concept is backward and the students' practical ability is not strong.}

The teaching mode is uniform, the professional curriculum is narrow, the teaching content is outdated, the theory and practice are out of line and the professional features are not obvious. It is a common problem in designing art schools. This will inevitably lead to the cultivation of students with a lack of knowledge, backward design concepts, students' practical ability is not strong, it is difficult to adapt to the needs of society and enterprises, resulting in a contradiction between supply and demand, resulting in structural imbalances: on the one hand, enterprises need a large amount of Talents, on the one hand, graduates can not find jobs, resulting in a huge waste of manpower and material resources. In the survey, when asked "the biggest problem in the cultivation of art design students in colleges and universities", 33.3\% of the units chose "the curriculum is behind the market demand " and $23.3 \%$ of the units chose "the practical ability of students is not Strong, $13.3 \%$ of the units chose "the design concept is backward." These problems are not solved and the difficulty of employment for art students is difficult to solve.

\section{Suggestions and countermeasures for cracking the employment difficulties of art design students}

3.1 Grasp the characteristics and take measures to strengthen the comprehensive quality of students and enhance their employment competitiveness

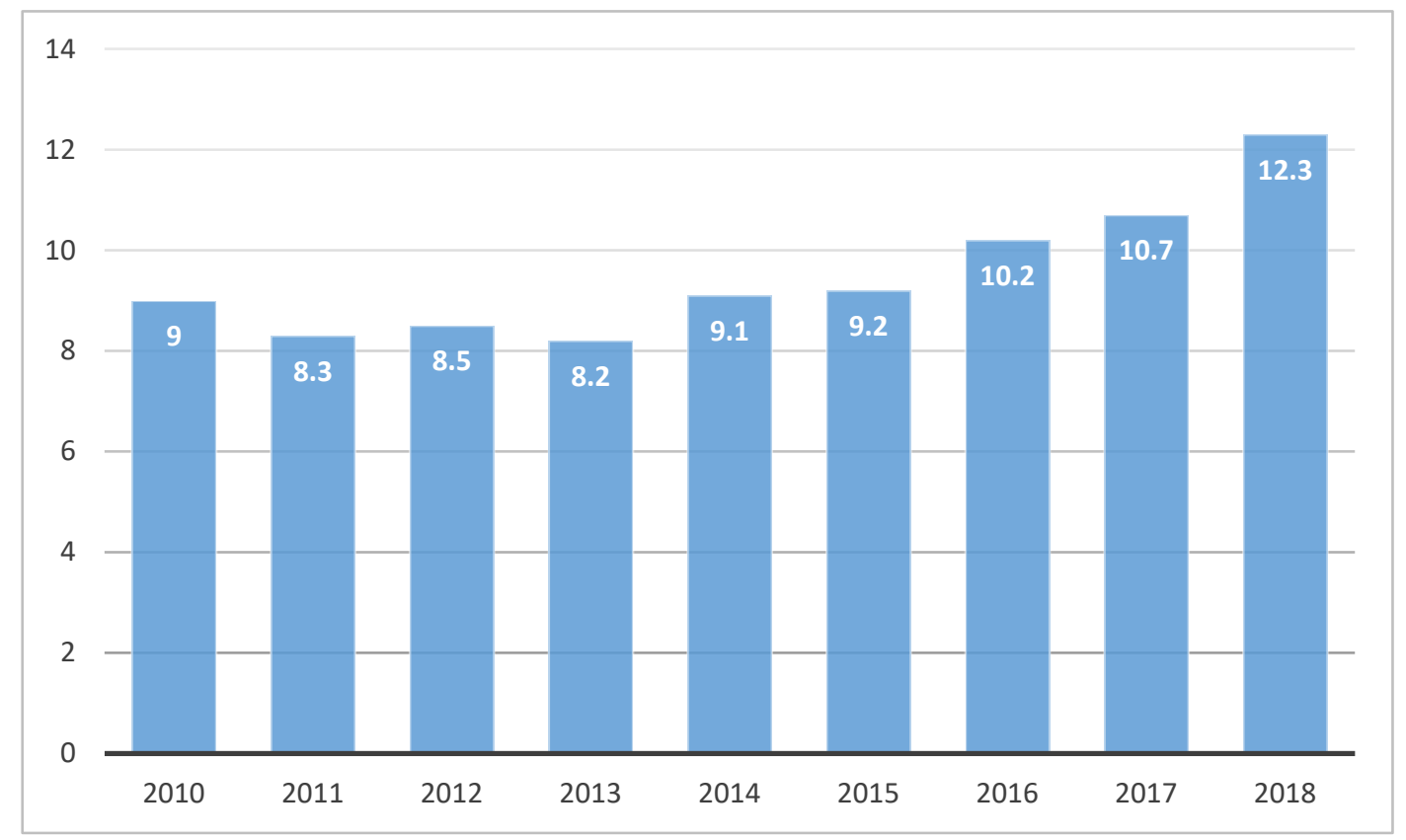

Figure 2 Demand for such talents is responding to the increase

The market is the best and the students who are welcomed by the market are the students who have succeeded in training. Therefore, in order to enhance students' employment competitiveness and improve their overall quality, it is necessary to improve the personnel training mechanism, 
grasp the characteristics of art design students and their growth rules and follow the principles of comprehensive development of morality, intelligence, body, beauty and labor. Sexually carry out professional competition activities and quality development activities and integrate the extracurricular activities in the classroom, so that art students can actively integrate into the collective life of society, schools, classes, associations, etc. and enhance their collective activities and in practice. Consciousness, teamwork awareness, improve their interpersonal skills, communication skills, expression skills, practical ability, innovative ability, build a reasonable intelligent structure, let students learn, learn to think, learn to cooperate, learn to innovate, learn to survive, Improve the internal drive of learning, promote students to be fully talented and stand in an invincible position in the fierce market competition ${ }^{[5]}$. The demand for such talents is responding to the increase, and its increase is shown in Figure 2.

\subsection{Carry out employment guidance in a phased and focused manner, form a systematic vocational guidance system and improve students' professional competitiveness}

As the cradle of talent training, colleges and universities play a vital role in the process of students' transformation from "collecting people" to "social people." In order to improve students' professional competitiveness, it is necessary to strengthen the "full-course" employment guidance in the process of student training in stages: focus on career planning and guide students in a timely manner according to the characteristics of the market and their own development. Positioning; the second grade focuses on quality education, guiding students to shape themselves according to the development requirements of the society, comprehensively improving the overall quality and job-seeking ability; the third-grade is focused on the education of entrepreneurship, the cultivation of entrepreneurship and the value education of employment and career choice. The employment mentality stimulates students' entrepreneurial awareness; the fourth grade focuses on the protection of situational policy education, employment skills and employment rights and improves the employability of students, thus forming a systematic vocational guidance system, so that students can correctly understand themselves and evaluate themselves. Comprehensively improve the overall quality, improve their own competitiveness, become a high-quality talents that match the economic and social development and maximize the matching of people and life.

\subsection{Strengthen market research, adjust traditional teaching content and cultivate professional design ability that matches students' market needs}

With the development of the market economy, the market plays a decisive role in the allocation of talents. It is an important measure to test the success of design art education. Therefore, we should be market-oriented, strengthen market research, analyze professional market demand, adjust talent training programs and reform the past knowledge-based ability, light common character, heavy-duty light guidance, heavy theory, light practice and light creativity. Practical, heavy art and light technology, heavy-hand ed traditional training mode, strengthen students' thinking training courses, cultivate students' divergent thinking and flexibility, creativity and change passive learning into active learning.

\section{Conclusion}

The ultimate goal of design art education is to develop students' ability to actually solve problems. Through school-enterprise cooperation, the school and enterprise support each other, mutual penetration, two-way intervention, resource interoperability and benefit sharing. The establishment of employment and practice bases can not only enable schools to better understand 
the reality of the market and industry, but also adjust the talent training program in a timely manner and provide students with a practical and practical platform for linking theory.

\section{Acknowledgement}

Research on visual communication professional talents training model based on knowledge transformation model /2018 Fujian youth and youth project (social science) jas180733

\section{References}

[1] Pablo Schyfter. Drawing Out by Drawing Into: Representation and Partnership in a Design-Science Collaboration [J]. Engaging Science, Technology, and Society, 2016,2.

[2] Bayburtlu Çimen,Ulusman Leyla. The influence of art education on jewelry design [J]. SHS Web of Conferences, 2016, 26.

[3] HONJO Michiyo. Design Archives of Musashino Art University.The Design Resources in the Visual Culture)[J]. Special issue of Japanese Society for the Science of Design, 2015, 22(2).

[4] KUROKAWA Taketo,ARAI Hiroshi,WADA Hiroki. "Local Art Study" and Entertainment Design [J]. Special issue of Japanese Society for the Science of Design, 2015, 22(3).

[5] KODAMA Sachiko,MUKAI Tamiko. Copyrightability in New Media Art and Design: Flowing Images of Ferrofluid Art as "Design Resources" on the Web[J]. Special issue of Japanese Society for the Science of Design, 2015, 22(2). 